Creative Commons User License: CC BY-NC-ND

Abstracted by: EBSCOhost, Electronic Journals Service (EJS), Google Scholar, Journal Seek, Scientific Commons,

Food and Agricultural Organization (FAO), CABI and Scopus
Journal of Agricultural Extension

Vol. 24 (2) April, 2020

ISSN(e): 24086851; ISSN(Print); 1119944X

http://journal.aesonnigeria.org

http://www.ajol.info/index.php/iae

Email: editorinchief@aesonnigeria.org

\title{
Effects of Social Media on Researchers' Attitude to Work at the International Institute of Tropical Agriculture, Oyo State, Nigeria
}

https://dx.doi.org/10.4314/jae.v24i2.2

\author{
Ayinde, Adefunke F. 0. \\ Department of Agricultural Administration, \\ College of Agricultural Management and Rural Development, \\ Federal University of Agriculture, Abeokuta, Nigeria. \\ Email: fadilatayinde@gmail.com \\ Phone: +2348035022359
}

\section{Fapojuwo, Oluwakemi E.}

Department of Agricultural Administration,

College of Agricultural Management and Rural Development,

Federal University of Agriculture, Abeokuta, Nigeria.

Email: kemifapojuwo@gmail.com

Phone: +2348062403148

\section{Soetan, Abayomi A.}

Department of Agricultural Extension and Rural Development, College of Agricultural Management and Rural Development,

Federal University of Agriculture, Abeokuta, Nigeria.

Email: soetan.sequence@gmail.com

Phone: +2348067170806

\section{Suleiman, Muhammed 0.}

Cassava Breeding Unit, International Institute of Tropical Agriculture (IITA)

Email: hamstrong0245@gmail.com

Phone: +2347035648652

\section{Adeyinka, Alexander 0 .}

Department of Agricultural Administration,

College of Agricultural Management and Rural Development,

Federal University of Agriculture, Abeokuta, Nigeria.

Email: adeyinkaalexander@gmail.com

Phone: +2348131354625

\section{Abstract}

This study assessed the effects of social media on researchers' work attitude at IITA, Ibadan, Oyo state, Nigeria. Proportionate sampling technique was used to select 82 respondents for the study through the use of questionnaire. Data collected were analysed using percentage, Chi-square and Pearson Product Moment Correlation (PPMC). Results showed that the frequently used media on a daily basis, were emails (87.7\%), Facebook (76.6\%) and WhatsApp (71.6\%) while Skype (24.7\%) and Twitter (21.0\%) were used on weekly basis. Researchers used social media to source for journals (14.8\%), collaborative research (38.2\%) and connection with families and 
Creative Commons User License: CC BY-NC-ND

Abstracted by: EBSCOhost, Electronic Journals Service (EJS), Google Scholar, Journal Seek, Scientific Commons,

Food and Agricultural Organization (FAO), CABI and Scopus
Journal of Agricultural Extension

Vol. 24 (2) April, 2020

ISSN(e): 24086851; ISSN(Print); 1119944X

http://journal.aesonnigeria.org

http://www.ajol.info/index.php/iae

Email: editorinchief@aesonnigeria.org

friends (41.9\%) as well as for online dating (7.4\%). Furthermore, $38.0 \%$ of the respondents accessed social media from their departmental office, personal office (29.7\%) and their individual homes (13.6\%). Researchers agreed that social media were essential office tools (37.0\%), retarded their work (3.7\%) as well as wasted their time (1.2\%). Chi-square analysis showed that there was significant relationship between the usage of social media and religion $\left(X^{2}=8.336\right.$, $p \leq 0.05)$, marital status $\left(X^{2}=14.81, p \leq 0.05\right)$ and rank/cadre of respondents $\left(X^{2}=23.03, p \leq 0.05\right)$ while PPMC analysis results showed a significant relationship between social media usage and age $(R=-$ $0.245, p \leq 0.05)$ as well as work experience $(R=-0.33, p \leq 0.005)$. Social media has both positive and negative effects on researchers' attitude to work. Social media usage should be controlled during working hours to improve the positive attitude of researchers towards work at IITA.

Key Words: Social media, work attitude, researchers.

\section{Introduction}

Social media can be defined as a platform where people communicate and utilise online platform while they are connected to the internet (Owusu-Acheaw and Larson, 2016; Carrigan, 2016). The advent of social media as form of communication has connected individuals throughout the world (Engler, 2019). Social media enables people to connect and interact not only with individuals but with many other people, speaking concurrently regardless of their locations. In addition, people may participate in a variety of activities while using the social media. For instance, they can download or upload photographs, videos, and electronically transfer information. Social media diminishes the problem of communication with others over long distances and expedites the ability for people to communicate at any time (Amedie, 2015 \& Hamada, 2018). Some of the most popular platforms in social media are Twitter, Linkedln, and Facebook, which gives people the ability to easily connect with friends, relatives, and co-workers and interaction between workers and management (Fusi and Zhang, 2018).

The popularity of social media has grown as a result of the rapid changes in technology since computers are now more mobile and can be used virtually anywhere. Organisations are increasingly using social media as a new way to reach customers more effectively and to spread news of their activities more rapidly. The widespread use of social media has brought in its stead new challenges to the workplace. One of these is the apparent addiction that the millennial generation has to Facebook and other social media applications like Twitter and Instagram, among others. Emails and the Internet are more commonly used by organisations and many of them have enacted policies regarding their use or misuse at work. The use of social media during work hours, particularly when accessed via a personal cell phone or computers brings a new set of challenges to personnel across the globe (Perry, 2016). 
Creative Commons User License: CC BY-NC-ND

Abstracted by: EBSCOhost, Electronic Journals Service (EJS), Google Scholar, Journal Seek, Scientific Commons,

Food and Agricultural Organization (FAO), CABI and Scopus
Journal of Agricultural Extension

Vol. 24 (2) April, 2020

ISSN(e): 24086851; ISSN(Print); 1119944X

http://journal.aesonnigeria.org

http://www.ajol.info/index.php/iae

Email: editorinchief@aesonnigeria.org

Social media can be considered a tremendous resource to the academia (Carrigan, 2016). For example, it has been credited with helping researchers think outside the box. In the same vein, researchers who utilise social media have been reported to be more productive (Brown et al 2016). The use of social media has aided researchers to become more productive by getting them intimated with contemporary issues. Researchers are therefore, better prepared to troubleshoot potential setbacks and are more likely to create good public relations through the work they do with the availability of social media.

Currently, about seventy percent of organisations around the world use social media. Studies (Owusu-Acheaw and Larson, 2015; Brown et al., 2016) have found that organisations that incorporate social media as a part of their business operations are most likely to grow faster than the companies who have not yet used it. The key benefit of social media is that it is seemingly free since researchers can access internet connections in workplace. Also, organisations can have their own platform to enhance research operations and researchers' communications by having inter-office social media platforms (e.g. intranet).

The popularity of social networks and their increasing application in the workplace present some concerns for employers, but all indications are that employers cannot hope to prevent social network use during work hours (Engler, 2019) Owusu-Acheaw and Larson, 2015; Brown et al., 2016). A dilemma therefore, arises where employees spend much more time on social media engaging in non-work related activities such as creating personal networks, checking on family and friends, streaming and downloading music and video, checking sports scores, following social bookmarks among others. This comes at a time when organisations on a global scale have been faced with a multitude of challenges and are looking for different ways to remain competitive. The development of social media policies and internet use policies by most employers is at an early stage as most employers do not have proper policies while some practices have dictated use of arbitrary control and restrictions. For instance, Perry (2016) has shown that one in five employees are distracted at work by social media. This study therefore, intends to contribute further to the body of growing literature on this issue.

\section{Purpose of the study}

The purpose of the study was to assess the effect of social media on researcher's work attitude. Specifically, the study:

- identify the various types of social media used by the researchers;

- determine the frequency of use of social media by researchers;

- identify the reasons for the researchers use of social media;

- describe the various methods used by researchers to access social media; and

- determine the effect of social media on researchers' attitude to work.

\section{Hypothesis}

The main hypothesis tested in this study was:

$\mathrm{H}_{\mathrm{o}}$ : There is no significant relationship between the personal characteristics of researchers' and the usage of social media. 
Creative Commons User License: CC BY-NC-ND

Abstracted by: EBSCOhost, Electronic Journals Service (EJS), Google Scholar, Journal Seek, Scientific Commons,

Food and Agricultural Organization (FAO), CABI and Scopus
Journal of Agricultural Extension

Vol. 24 (2) April, 2020

ISSN(e): 24086851; ISSN(Print); 1119944X

http://journal.aesonnigeria.org

http://www.ajol.info/index.php/jae

Email: editorinchief@aesonnigeria.org

\section{Methodology}

This study was carried out at the International Institute of Tropical Agriculture (IITA) in Ibadan, Oyo state, Nigeria. Ibadan is situated between Longitude $7.37756^{\circ} \mathrm{N}$ and Latitude $3.90591^{\circ} \mathrm{E}$ (LongitudeLatitude.org, 2015), while Oyo State is located in the South-West geopolitical zone of Nigeria. Oyo state of was one of the three states carved out of the former Western state of Nigeria in 1976. Oyo state is bounded in the North by Kwara state, in the east by Osun state, in the south by Ogun state and in the west by partly Ogun state and partly by the Republic of Benin.

The International Institute of Tropical Agriculture (IITA) works with institutions, groups and NGOs, to enhance crop quality and productivity reduce producers and consumers' risks and generate wealth from agriculture, with the ultimate goals of reducing hunger, malnutrition and poverty. The institute was established in 1967 and its headquarters in Ibadan, Nigeria, with several research stations across Africa. IITA is a non-profit organisation governed by a board of Trustees supported by several countries and Consultative Group on International Agricultural Research (CGIAR). Also, IITA's resources for development (R4D) focus on addressing the development needs of tropical countries.

The population of the study was the total number of researchers in the various research departments in IITA, which totalled 254. A proportionate sampling technique was used for the study by selecting eighty-two (82) respondents from all the research departments. Primary data were collected through the use of questionnaire to elicit information from the respondents in order to accomplish set study objectives. Supplementary information was obtained from journals, internet materials and other related literature.

Table 1: Sample frame of researchers at IITA

\begin{tabular}{lcc}
\hline Department & Population & $\begin{array}{l}\text { Sample size } \\
\text { (33\%) }\end{array}$ \\
\hline Yam breeding & 50 & 17 \\
Cassava breeding & 70 & 23 \\
Harvest plus & 38 & 13 \\
Maize unit & 56 & 19 \\
West African Rice Development Agency (WARDA) & 31 & 10 \\
Total & $\mathbf{2 4 5}$ & $\mathbf{8 2}$ \\
\hline
\end{tabular}

Both descriptive and inferential statistical tools were used in this study. The descriptive tools (means, percentages and tables) were obtained using Microsoft Excel while the inferential tools analysis (Chi-square and Pearson Product Moment Correlation 
Creative Commons User License: CC BY-NC-ND

Abstracted by: EBSCOhost, Electronic Journals Service (EJS), Google Scholar, Journal Seek, Scientific Commons,

Food and Agricultural Organization (FAO), CABI and Scopus

http://eoi.citefactor.org/10.11226/v24i2
Journal of Agricultural Extension

Vol. 24 (2) April, 2020

ISSN(e): 24086851; ISSN(Print); 1119944X

http://journal.aesonnigeria.org

http://www.ajol.info/index.php/iae

Email: editorinchief@aesonnigeria.org

[PPMC] for testing the null hypothesis) were obtained using the Statistical Package for the Social Sciences and Service Solution (SPSS) version 21.0.

\section{Results and Discussion}

\section{Types of Social Media Used}

Results in Table 3 reveal the types of social media used by researchers include, email (95.1\%), Facebook (92.6\%) and WhatsApp (87.6\%) accounted for the most accessed social media tools by the researchers. However, blogs (17.3\%), Flickr (16.0) and Viber (12.3\%) accounted for the least used social media tools by researchers. The high level use of email is very commendable and portends the researchers has been a group of overtly conscientious employees because this type of social media is not distractive (Perry, 2016). However, the high rate of use of Facebook and WhatsApp may be worrisome if not dedicated to work related purposes, especially during the office hours (Brown et al., 2016). The popularity of Email, Facebook and WhatsApp in the organisation may however be a pointer to the fact that there is great institutional support in the provision of uninterrupted internet facility in IITA. The likes of blog, flicker and Viber were the least recognised social media in the organisation possibly because their advent into the social media family is more recent and the researchers are just getting to learn them, relative to the earlier ones (email, Facebook and WhatsApp), which may have satisfied the social need of these researcher to a great extent.

Table 3: Types of social media used

\begin{tabular}{ll}
\hline Variables & Yes \\
\hline E-mail & 95.1 \\
Facebook & 92.6 \\
WhatsApp & 87.6 \\
YouTube & 80.2 \\
Twitter & 59.3 \\
BBM & 43.2 \\
Skype & 40.7 \\
2go & 29.6 \\
Linkedln & 23.5 \\
Viber & 12.3 \\
Blog & 17.3 \\
Flickr & 16.0 \\
\hline
\end{tabular}

Source: Field survey (2015) 
Creative Commons User License: CC BY-NC-ND

Abstracted by: EBSCOhost, Electronic Journals Service (EJS), Google Scholar, Journal Seek, Scientific Commons,

Food and Agricultural Organization (FAO), CABI and Scopus

http://eoi.citefactor.org/10.11226/v24i2
Journal of Agricultural Extension

Vol. 24 (2) April, 2020

ISSN(e): 24086851; ISSN(Print); 1119944X

http://journal.aesonnigeria.org

http://www.ajol.info/index.php/iae

Email: editorinchief@aesonnigeria.org

\section{Frequency of Social Media Usage}

The majority ( $87.7 \%)$ of the respondents used email on daily basis (Table 4$)$, while $76.6 \%$ used Facebook on daily basis. Also $71.6 \%$ of the respondents used WhatsApp on a daily basis, while $35.8 \%$ used Twitter on daily basis. This implies that use of social media was common among respondents in the organisation. The findings also indicated that a large section of the respondents visit social media either on daily or weekly basis, which signified presence of virtual interaction within the organisation. This is expected, given the need for a good and prompt dissemination of information among the workforce and as a complement for socialisation with friends and families. This finding conforms with Genner and Suss (2017) and Kizgin et al, (2019), who opined that social media has bridged the digital divide with exchange of veritable information and socialisation within a very short time, to achieve personal objectives which are beneficial and or deleterious to personal development.

Table 4: Frequency of use of social media

\begin{tabular}{lccccc}
\hline Items & Daily & Weekly & Fortnightly & Monthly & Never \\
\hline E-mail & 87.7 & 7.4 & 1.2 & 2.5 & 1.2 \\
Facebook & 76.6 & 16.0 & - & 1.2 & 6.2 \\
WhatsApp & 71.6 & 14.8 & 1.2 & - & 12.3 \\
YouTube & 25.9 & 40.7 & 14.8 & 2.5 & 16.0 \\
BBM & 23.5 & 8.6 & 2.5 & 1.2 & 51.8 \\
Twitter & 35.8 & 21.0 & 4.9 & 2.5 & 48.1 \\
Skype & 7.4 & 24.7 & 4.9 & 3.7 & 59.2 \\
2go & 7.4 & $10(12.3)$ & $4(4.9)$ & $5(6.2)$ & $56(69.2)$ \\
Linkedln & 1.2 & $11(13.6)$ & $8(9.9)$ & $5(6.2)$ & $56(69.2)$ \\
Flickr & 3.7 & $7(8.9)$ & $3(3.7)$ & $1(1.2)$ & $68(83.9)$ \\
Blog & 4.9 & $4(4.9)$ & $4(4.9)$ & - & $69(85.1)$ \\
Viber & 3.7 & $2(2.5)$ & $2(2.5)$ & $1(1.2)$ & $73(90.1)$ \\
\hline
\end{tabular}

Source: Field survey (2015)

\section{Reasons for Using Social Media}

Fifty-point six percent of the researchers never utilised the social media for the purpose of publishing or maintaining blog(s) nor engaged in online dating, while, $49.4 \%$ never engaged in video conferencing though $41.8 \%$ sometimes connected with other registered professionals through the media. Also, $39.5 \%$ of the researchers sometimes sourced for agricultural journals on social media while $34.5 \%$ transfer files, text and make phone calls to colleagues through the media. Furthermore, $32.1 \%$ of researchers often used social media for connecting with friends and families while only $17.3 \%$ often used social media to mobilise stakeholders in agriculture for scheduled meetings. From these results, it seemed that social media is generally gaining ground as a veritable tool to be used for work- 
Creative Commons User License: CC BY-NC-ND

Abstracted by: EBSCOhost, Electronic Journals Service (EJS), Google Scholar, Journal Seek, Scientific Commons,

Food and Agricultural Organization (FAO), CABI and Scopus
Journal of Agricultural Extension

Vol. 24 (2) April, 2020

ISSN(e): 24086851; ISSN(Print); 1119944X

http://journal.aesonnigeria.org

http://www.ajol.info/index.php/iae

Email: editorinchief@aesonnigeria.org

related purposes even as they are also being well utilised for social purposes. This conforms with the findings of Couldry (2015), affirms that social networks are typical characterisations of human behaviour to fulfil the need to communicate and connect with people they know, meet new people who share their common interests, collaborate, participate and share information and knowledge as well as gain new knowledge within and without organisations.

Table 5: Reasons for using social media

\begin{tabular}{lll}
\hline Reasons & Mean & S.D \\
\hline Sourcing for research materials & 3.46 & 1.08 \\
Sourcing for journals & 3.31 & 1.06 \\
For collaborative effort with other researchers & 3.54 & 1.00 \\
Publish research findings & 2.86 & 1.12 \\
Networking with research institutes and Universities & 3.13 & 1.20 \\
Publish and maintain blog(s) & 2.16 & 1.33 \\
Transfer files, text and make phone calls to colleagues & 3.78 & 0.95 \\
Connect other registered professionals & 3.21 & 1.04 \\
Video conferencing & 2.10 & 1.04 \\
Mobilise stakeholders in agriculture for scheduled meetings & 2.68 & 1.12 \\
Platform for audio-visual information delivery & 2.14 & 1.43 \\
Online service consultation on social media & 3.29 & 1.20 \\
Online dating & 1.99 & 1.26 \\
Chatting and group discussion & 3.64 & 1.08 \\
Download latest music and movies & 2.78 & 1.28 \\
Connecting with friends and family & 4.03 & 1.00 \\
Upload my pictures and videos & 3.13 & 1.18 \\
Read electronic magazines/newspaper & 3.68 & 1.08 \\
\hline Source: Fleld Survey, 2015
\end{tabular}

Source: Field Survey, 2015

\section{Methods Used to Access Social Media}

Results in Table 6 revealed the methods used by the sampled researchers to access social media. According to the result, few (38.3\%) of the respondents often accessed social media from their departmental offices, $29.7 \%$ often accessed social media from their personal office while $21.0 \%$ of the respondents sometimes access social media through the services from the library. Only $21.0 \%$ always accessed social media from their organisation's information and communication technology centre, while $13.6 \%$ of the respondents often access social media from their individual home.

This finding indicates that many respondents in the organisation deployed the use of social media at work mostly in their office, this is indicative of the fact the institution has enabling environment in the use of social media for improved job disposition and efficiency. This will in turn positively affect the performance of these researchers. This view agrees with Corcoran and Duane (2018), that effective communication through the use of the social media in institutions would be enhanced by improved organisational and culture, which will in turn promote knowledge sharing and development. This in turn positively boost users' accomplishments if they are able to meet objectives of social media usage (Kizgin et al., 2019). 
Creative Commons User License: CC BY-NC-ND

Abstracted by: EBSCOhost, Electronic Journals Service (EJS),

Google Scholar, Journal Seek, Scientific Commons,

Food and Agricultural Organization (FAO), CABI and Scopus
Journal of Agricultural Extension

Vol. 24 (2) April, 2020

ISSN(e): 24086851; ISSN(Print); 1119944X

http://journal.aesonnigeria.org

http://www.ajol.info/index.php/iae

Email: editorinchief@aesonnigeria.org

Table 6: Various methods used by respondents to access social media

\begin{tabular}{lll}
\hline Items & Mean & S.D \\
\hline Patronage of commercial cybercafés & 2.06 & 1.23 \\
Through services from the library & 2.58 & 1.3 \\
Personal office & 3.53 & 1.20 \\
Departmental office & 3.29 & 1.09 \\
From home using WiFi & 3.01 & 1.20 \\
Using GSM & 3.55 & 1.16 \\
ICT Department & 2.99 & 1.46 \\
\hline
\end{tabular}

Source; Field survey, 2015

\section{Effect of Social Media on Work Attitude}

Results in Table 7 show the perceptions of the researchers about social media. Findings showed that the majority $(49.3 \%)$ of the researchers strongly agreed that social media was an essential tool in an organisation while $56.8 \%$ of the researchers agreed that social media aid in research work. Also, $16.0 \%$ of the researchers strongly disagreed that social media tends to be a means of distraction to researchers while $40.7 \%$ of researchers strongly disagreed that social media lowers their productivity as a researcher. Furthermore, $18.5 \%$ of the researchers strongly disagreed that using social media for work and socialisation gives them a sense of fulfilment. This implies that respondents viewed social media as very important for their work and may have positive effects on their work attitude if managed properly, for organisational workforce efficiency in the future. This agrees with the basic findings of scholars who further surmised that social media engenders formation of employees' social capital which further improve knowledge transfer (Cao et al., 2016; Cetinkaya \& Rashid, 2018). Social media can therefore, facilitate interactions which builds closer friendship and trust as well as commonality of opinion towards improvement of work attitude for organisational development.

Table 7: Effect of social media on respondents' attitude

\begin{tabular}{lll}
\hline Perceptual Statements & Mean & S.D \\
\hline It is an essential tool in an organisation & 4.24 & 0.97 \\
It negatively influence my concentration at my research work & 2.46 & 1.24 \\
It enhances my work as a researcher & 3.69 & 0.97 \\
Social media usage can be frustrating & 2.74 & 1.42 \\
They distract researchers when at work & 2.86 & 1.18 \\
They give sense of fulfilment when used for work and socialisation purposes & 3.14 & 1.34 \\
& & \\
They lower productivity of researchers & 1.88 & 0.96 \\
Improves ones proficiency in computer usage & 3.30 & 1.19 \\
Social media aid in research work & 3.99 & 0.83 \\
They are sheer waste of time & 1.89 & 0.86 \\
I think social media are meant for the youths/ students and not researchers & 1.90 & 1.08 \\
& & \\
Specifically designated social media site for staff will improve work efficiency & 3.28 & 1.25 \\
Social media promote moral decadence (pornographies, indecent dressing etc.) & 3.72 & 1.17 \\
I think social media should be blocked by the IITA's ICT department & 1.70 & 1.00 \\
\hline
\end{tabular}

Source: Field survey, 2015 
Creative Commons User License: CC BY-NC-ND

Abstracted by: EBSCOhost, Electronic Journals Service (EJS), Google Scholar, Journal Seek, Scientific Commons,

Food and Agricultural Organization (FAO), CABI and Scopus

http://eoi.citefactor.org/10.11226/v24i2
Journal of Agricultural Extension

Vol. 24 (2) April, 2020

ISSN(e): 24086851; ISSN(Print); 1119944X

http://journal.aesonnigeria.org

http://www.ajol.info/index.php/iae

Email: editorinchief@aesonnigeria.org

\section{Relationship between Personal Characteristics and Use of Social Media}

The results show that there is no significant relationship between sex $\left(x^{2}=10.45\right.$, $p \leq 0.05)$. The implies that sex does not determine the usage of social media in the study area. Also, significant relationship exists between religion $\left(x^{2}=8.336, p \leq 0.05\right)$, marital status $\left(x^{2}=14.81, d f=8, p \leq 0.05\right)$ rank or cadre $\left(x^{2}=23.03, p \leq 0.05\right)$ and the usage of social media. The result shows that marital status, religion and rank or cadre are highly related to the usage of social media in the study area. Rank and cadre have influence on use of social media to accomplish organisational goals, lower cadre staff tend to use social media more for job accomplishments (Brown et al., 2016).

Significant relationship exists between Age $(R=-0.245, p \leq 0.05)$ and work experience $(R=-0.33 p \leq 0.05)$ of respondents relative to the usage of social media, while there was no significant relationship between pay grade $(R=0.029, p \geq 0.05)$ and the usage of social media. Age and work experience have been adjudged as important factors affecting the use of social media in academic organisation (OwusuAcheaw and Larson, 2015).

Table 8: Relationship between personal characteristics of respondents and the use of social media

\begin{tabular}{|c|c|c|}
\hline Variables & Chi-square & df \\
\hline Sex & 10.45 & 4 \\
\hline Marital status & $14.81^{*}$ & 8 \\
\hline Religion & $8.336^{*}$ & 4 \\
\hline Rank or cadre & \multirow{2}{*}{\multicolumn{2}{|c|}{$\begin{array}{c}R \\
-0.245^{*}\end{array}$}} \\
\hline Age & & \\
\hline Work experience & \multicolumn{2}{|c|}{$-0.33^{\star *}$} \\
\hline Pay grade & \multicolumn{2}{|c|}{0.029} \\
\hline
\end{tabular}

Source; Field Survey, 2015

${ }^{*} \mathrm{p} \leq 0.05$

\section{Conclusion and Recommendations}

Factors which affect use of social media among researchers are marital status, religion and rank or cadre as well as age and work experience. Policy makers and executives of organisations therefore, need to enhance the research environment with the use of social media to improve researchers' efficiency especially in the area of sourcing for journals while ensuring that distractions of workers arising from social media usage are reduced to the barest minimum, for improved efficiency of the workforce.

\section{Acknowledgement}

We wish to immensely appreciate the efforts of Dr. Najimu A. Adetoro of Cassava Breeding Unit, IITA during the data collection stage. 
Creative Commons User License: CC BY-NC-ND

Abstracted by: EBSCOhost, Electronic Journals Service (EJS), Google Scholar, Journal Seek, Scientific Commons,

Food and Agricultural Organization (FAO), CABI and Scopus

http://eoi.citefactor.org/10.11226/v24i2
Journal of Agricultural Extension

Vol. 24 (2) April, 2020

ISSN(e): 24086851; ISSN(Print); 1119944X

http://journal.aesonnigeria.org

http://www.ajol.info/index.php/jae

Email: editorinchief@aesonnigeria.org

\section{References}

Abbie Brown, John Cowan and Tim Green (2016). Faculty productivity: Using social media and measuring its impact. Educause Review, May 2, 2016 Downloaded at https://er.educause.edu/articles/2016/5/faculty-productivity-using-social-media-andmeasuring-its-impact. Accessed on April 27, 2019.

Amedie, J. (2015). The impact of social media on society. Advanced writing: Pop Culture Intersection, 2. Scholar Commons, Santa Clara University, 19pp. https://scholarcommons.scu.edu/cgi/viewcontent.cgi?article=1002\&context=engl 176

Cao, X., Guo, X., Vogel, D. and Zhang, X. (2016). Exploring the influence of social media on employees work performance. Internet Research, 26(2), 529-545.

http://dx.doi.org/10.1108/IntR-11-2014-0299

Çetinkaya, A. S. and Rashid, M. (2018). The effect of use of social media on employee job performance. Internet Uygulamalari Yönetimi Dergisi (Journal of Internet Application and Management), 9(2), 5-20. http://dx.doi.org/10.34231/iuyd.437726

Couldry, N. (2015). Social media: Human life. Social Media and Society, 1(1). Sage Publishers, UK. https://doi.org/10.1177/2056305115580336

Corcoran N. and Duane, A. (2018). Using social media to enable staff knowledge sharing in higher education institutions. Australasian Journal of Information Systems, 22. http://dx.doi.org/10.3127/ajis.v22i0.1647

Engler, M. (2019). Does social media make us more or less connected? Morning Side Centre for Teaching Social Responsibility. Downloaded on February 29, 2020 at: https://www.morningsidecenter.org/teachable-moment/lessons/does-social-mediamake-us-more-or-less-connected

Fusi, F. and Zhang, F. (2018). Social media communication in the workplace: Evidence from the public employees' networks. Review of Public Personnel Administration, Online publishing, October 25, 2018. https://doi.org/10.1177/0734371X18804016

Genner, H. and Suss, D. (2017). Socialisation as media effect. The international encyclopaedia of media effects. John Wiley and Sons Inc.

Hamada, B. I. (2018). Social media, a turning point into global journalism identity and ethics. IntechOpen, 80255. http://dx.doi.org/10.5772/intechopen.80255

Kizgin, H., Jamal, A., Rana, N., Dviwedi, Y. and Weerakkody, V. (2019). The impact of social networking sites on socialization and political engagement: Role of acculturation. Technological Forecasting and Social Change, 145, 503-512. https://doi.org/10.1016/j.techfore.2018.09.010

LongitudeLatitude.org: 2015. https://latitudelongitude.org/about. Accessed on October 27, 2019.

Mark Carrigan (2016). Social media for academics, Sage Publishers, Ltd. 208pp. 
Creative Commons User License: CC BY-NC-ND

Abstracted by: EBSCOhost, Electronic Journals Service (EJS),

Google Scholar, Journal Seek, Scientific Commons,

Food and Agricultural Organization (FAO), CABI and Scopus

http://eoi.citefactor.org/10.11226/v24i2
Journal of Agricultural Extension

Vol. 24 (2) April, 2020

ISSN(e): 24086851; ISSN(Print); 1119944X

http://journal.aesonnigeria.org

http://www.ajol.info/index.php/iae

Email: editorinchief@aesonnigeria.org

Owusu-Acheaw, M. and Larson, A. G. (2015). Use of social media and its impact on academic performance of tertiary institution students: A study of students of Koforidua Polytechnic, Ghana. Journal of Education and Practice 6(6), 94-101. https://www.iiste.org/Journals/index.php/JEP/article/view/20048/20406

Perry, P. (2016). Is social media killing your workplace's productivity? Downloaded at: https://bigthink.com/philip-perry/is-social-media-killing-your-workplaces-productivity Accessed on April 27, 2019. 